\title{
Penanaman Karakter Kejujuran Melalui Kantin Anti Korupsi pada Siswa SD/MI Ngargorejo, Ngemplak, Boyolali
}

\author{
Rita Pramujiyanti Khotimah ${ }^{1}$, Doni Suryo Putro ${ }^{2}$, Ginanjar Wahyu Utomo ${ }^{3}$, Anisa Fera \\ Hidayah $^{4}$, Nurul Endah Astrianti ${ }^{5}$, Yusti Ratna Sari ${ }^{6}$, Tiara Risti Alfanani ${ }^{7}$, Heny Tri \\ Muthmainnah $^{8}$, Mazliza ${ }^{9}, Z_{\text {Zakiah }}{ }^{10}$

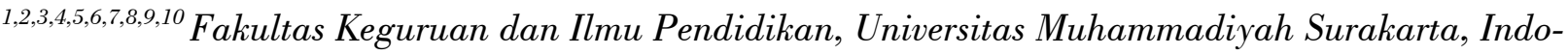 \\ nesia
}

\section{INFORMASI ARTIKEL}

\section{Histori Artikel:}

Submit: 18 Mei 2020

Revisi: 1 Juni 2020

Diterima: 27 Juni 2020

Publikasi: 1 Juli 2020

Periode Terbit: Juli 2020

\section{Kata Kunci:}

karakter,

kejujuran,

kantin anti korupsi

\section{Correspondent Author:}

Rita Pramujiyanti Khotimah

Fakultas Keguruan dan Ilmu Pendidikan

Universitas Muhammadiyah Surakarta,

Indonesia

Email: rpramujiyanti@ums.ac.id

\begin{abstract}
ABSTRAK
Kejujuran merupakan salah satu karakter yang penting ditanamkan semenjak dini pada siswa. Melalui kejujuran diharapkan bisa dihasilkan siswa yang cerdas tidak hanya secara intelektual, namun juga cerdas secara moral. Program ini bertujuan untuk menanamkan karakter kejujuran melalui kantin anti korupsi pada siswa SD/MI Ngargorejo, Ngemplak, Boyolali. Metode pelaksanaan program melalui penyuluhan dan pendampingan. Hasil pelaksanaan program menunjukkan bahwa nilai nilai karakter kejujuran siswa yang diinternalisasikan dalam kantin anti korupsi di SD/ MI Ngargorejo, Ngemplak, Boyolali telah tertanamkan dengan baik. Siswa sudah menunjukkan sikap jujur, disiplin dan mandiri dalam program kantin anti korupsi. Keberadaan kantin anti korupsi dengan teknik pelayanan self-service system dapat dijadikan sebagai media yang baik dalam penanaman karakter kejujuran siswa karena bisa melahirkan sikap dan tindakan siswa yang positif.
\end{abstract}

\section{Pendahuluan}

Undang-Undang Republik Indonesia no 20 Tahun 2003 tentang Sistem Pendidikan Nasional pasal 3 menyebutkan bahwa Pendidikan nasional berfungsi mengembangkan kemampuan dan membentuk watak serta peradaban bangsa yang bermartabat dalam rangka mencerdaskan kehidupan bangsa, bertujuan untuk berkembangnya potensi peserta didik agar menjadi manusia yang beriman dan bertakwa kepada Tuhan Yang Maha Esa, berakhlak mulia, sehat, berilmu, cakap, kreatif, mandiri, dan menjadi warga negara yang demokratis serta bertanggung jawab. Potensi-potensi peserta didik yang akan dikembangkan berdasarkan Undang-Undang ini pada dasarnya adalah karakter-karakter yang dimiliki oleh peserta didik tersebut.
Karakter adalah "nilai dasar yang membangun pribadi seseorang, terbentuk baik karena pengaruh hereditas maupun pengaruh lingkungan, yang membedakannya dengan orang lain, serta diwujudkan dalam sikap dan perilakunya dalam kehidupan sehari-hari" (Samani \& Hariyanto, 2013). Staf Ahli Mendikbud Bidang Pembangunan Karakter, Budhiman (2017), menyatakan 18 nilai-nilai yang perlu dikembangkan dalam gerakan penguatan pendidikan yaitu: (1) religius, (2) jujur, (3) toleransi, (4) disiplin, (5) kerja keras. (6) kreatif, (7) mandiri, (8) demokratis, (9) rasa ingin tahu, (10) semangat kebangsaan, (11) cinta tanah air, (12) menghargai prestasi, (13) bersahabat, (14) cinta damai, (15) gemar membaca, (16) peduli lingkungan, (17) peduli sosial, dan (18) tanggung jawab. 
Salah satu karakter yang perlu ditekankan semenjak dini adalah kejujuran. Dari Abdullah Ibnu Mas'ud, Rasulullah SAW bersabda yang artinya: "Berpeganglah kamu dengan kejujuran karena kejujuran itu membawa kebajikan. dan kebajikan itu membawa ke surga "(HR. Bukhari dan Muslim). Jujur berarti menyatakan sesuatu dengan apa adanya, transparan, Antara yang diucapkan dengan yang dilakukan tidak berbeda, bisa dipercaya ( amanah, trustworthiness), dan tidak melakukan kecurangan (no cheating) (Samani \& Hariyanto, 2013).

Penanaman karakter kejujuran siswa di sekolah dapat dilaksanakan salah satunya dengan mengadakan kantin anti korupsi. Kantin anti korupsi merupakan salah satu gagasan yang diadakan oleh Komisi Pemberantasan Korupsi (KPK) dalam rangka memperingati hari korupsi tanggal 9 Desember. Kantin anti korupsi bertujuan untuk melatih kejujuran setiap individu yang bertransaksi di kantin kejujuran tersebut. Hal ini dilakukan oleh KPK sebagai wujud implementasi dari Undang-Undang Republik Indonesia Nomor 30 Tahun 2002 tentang Komisi Pemberantasan Tindak Pidana Korupsi Pasal 13c bahwa dalam melaksanakan tugas pencegahan sebagaimana dimaksud dalam Pasal 6 huruf d, Komisi Pemberantasan Korupsi berwenang melaksanakan langkah atau upaya pencegahan menyelenggarakan program pendidikan anti korupsi pada setiap jenjang pendidikan.

Penelitian yang mendukung pengadaan kantin anti korupsi telah dilaksanakan oleh Atika (2016) yang menyebutkan bahwa kantin kejujuran merupakan media pendidikan karakter yang relevan dalam menanamkan nilai-nilai kebaikan termasuk akhlak kepada siswa. Al Habib (2013) juga menyatakan bahwa kantin kejujuran merupakan sarana yang tepat untuk melatih kejujuran siswa di MI Setia Bhakti. Senada dengan Arrahim (2016) dan Al Habib (2013), Alfurkan dan Marzuki (2020) menyebutkan bahwa kantin kejujuran merupakan salah satu bentuk pendidikan anti korupsi.

Program kegiatan KKN-dik ini bertujuan untuk menanamkan karakter kejujuran melalui kantin anti korupsi pada siswa SD/MI Ngargorejo, Ngemplak, Boyolali.

\section{Metode Pelaksanaan}

Metode pelaksanaan kegiatan ini adalah bersifat observatif (Fitriansyah, Fatinah, \& Syahril, 2020). Metode pelaksanaan kegiatan ini adalah: a) Pendidikan Masyarakat, berupa penyuluhan yang bertujuan untuk meningkatkan pemahaman serta kesadaran siswa SD/MI Ngargorejo, Ngemplak, Bo- yolali akan pentingnya penanaman kejujuran siswa sejak dini, b) Advokasi, yang berupa pendampingan terhadap siswa SD/MI Ngargorejo, Ngemplak, Boyolali dalam pelaksanaan program kantin anti korupsi.

\section{Hasil Pelaksanaan dan Pembahasan}

Program kegiatan KKN-dik ini dilaksanakan di SD/MI Desa Ngargorejo Ngemplak Boyolali selama tiga minggu, yaitu pada tanggal 3- 24 Februari 2019. Diawali pada tanggal 3 Februari 2019 tim mahasiswa KKN memberikan penyuluhan pada siswa yang berisi penjelasan mengenai pentingnya aqidah akhlak yang baik dalam segala hal, termasuk dalam pelaksanaan kantin anti korupsi sebagai program penanaman karakter kejujuran.

Kegiatan selanjutnya berupa pendampingan dalam pelaksanaan program kantin anti korupsi. Deskripsi kantin anti korupsi sebagai media penanaman karakter kejujuran siswa di SD/MI Ngargorejo, Ngemplak, Boyolali sebagai berikut. Kantin anti korupsi yang terbentuk di SD/MI Ngargorejo Ngemplak Boyolali masih sangat sederhana bahkan belum layak untuk menjadi sebuah kantin. Kantin yang berada di SD/MI ini hanya berbentuk dua buah kardus yang berisi berbagai macam jajanan anak yang diletakkan di atas meja (Gambar 1) sebagai tempat meletakkan jajanan tersebut.

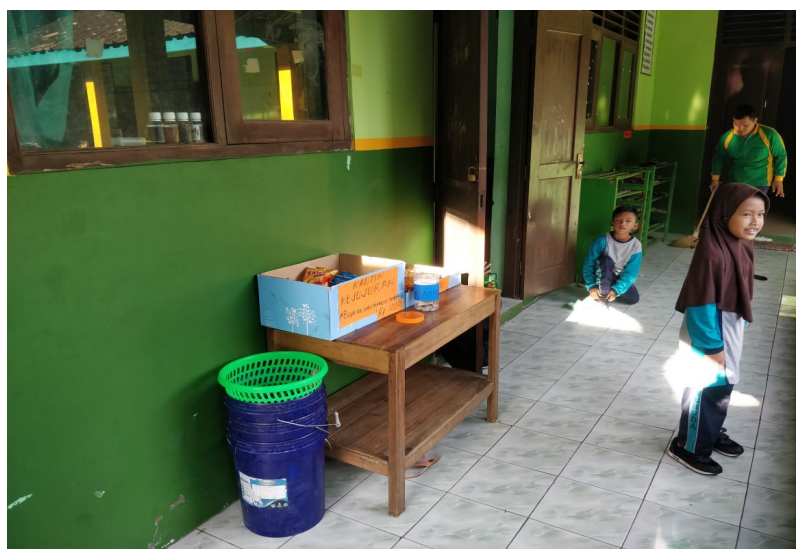

Gambar 1. Kardus yang Berisi Berbagai Macam Jajanan Anak

Selain kardus tempat jajanan, juga disediakan kotak kardus sebagai tempat membayar dan mengambil kembalian sendiri. Di dalam wadah tersebut terdapat sebuah kertas berwarna biru dengan ukuran sedang yang didalamnya tertulis kalimat "Allah SWT Maha Melihat apa yang kita perbuat “ (Gambar 2). Secara tidak langsung tulisan yang terdapat di dalam kotak tempat uang mencerminkan apa yang sebenarnya diharapkan melalui kantin anti 
korupsi yaitu kejujuran dalam berperilaku. Di kantin $\mathrm{SD} / \mathrm{MI}$ tersebut tidak ada orang yang bertugas menjadi penjual ataupun menjadi penunggu kantin. Di sini, siapapun yang ingin membeli jajanan maka dia harus melayani dirinya sendiri. Artinya, seorang siswa bisa bertindak sebagai pembeli sekaligus penjual.

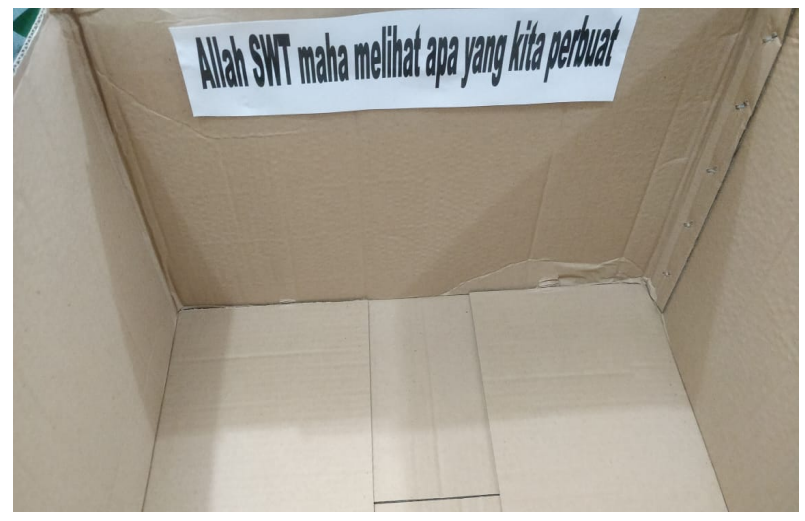

Gambar 2. Kotak Sederhana Tempat Membayar dan Mengambil Uang Kembalian

Penanaman karakter kejujuran terjadi pada saat siswa melakukan transaksi jual beli di kantin anti korupsi. Melalui kantin anti korupsi, siswa dilatih untuk melakukan kejujuran yaitu kejujuran dalam berinteraksi karena siswa melakukan transaksi jual beli di kantin anti korupsi tanpa ada orang lain yang menunggu kantin tersebut (Gambar 3).

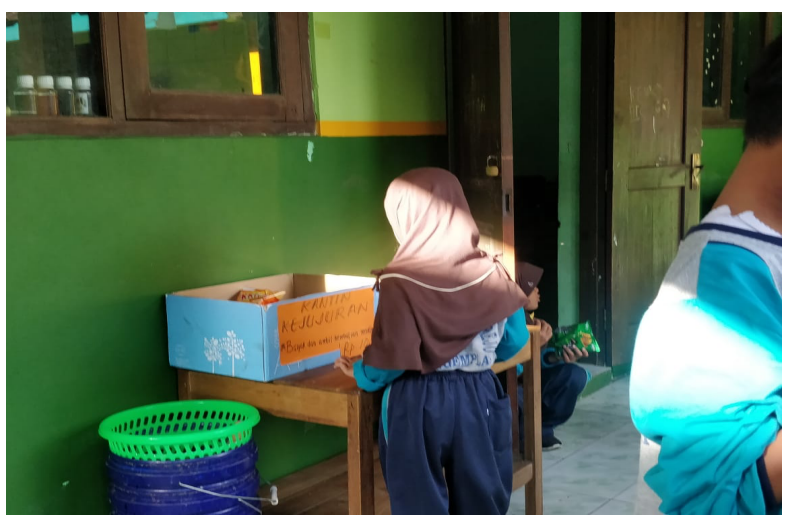

Gambar 3. Proses Transaksi Siswa pada Kantin Anti Korupsi

Berdasarkan hasil observasi, siswa terlihat lebih antusias dan lebih sering membeli aneka makanan anak di kantin anti korupsi daripada ke penjual lain yang letaknya di luar pagar sekolah. Hanya beberapa siswa saja yang membeli ke penjual lain. Mengenai hal tersebut, bapak/ibu guru juga menjelaskan bahwa siswa memang lebih sering mem- beli jajanan di kantin anti korupsi daripada ke penjual lain, padahal para guru tidak pernah memaksa siswa untuk jajan di kantin anti korupsi saja.

Respon siswa terhadap kantin anti korupsi sangat bagus. Hal ini terlihat dari jajanan di kantin anti korupsi setiap harinya selalu habis terjual. Hasil wawancara dengan siswa menyatakan bahwa mereka lebih senang jajan di kantin anti korupsi karena pilihan jajanan beraneka ragam dan letaknya dekat dengan kelas mereka.

Contoh nyata dari tindakan jujur siswa melalui program kantin anti korupsi sebagaimana disampaikan oleh para guru adalah siswa melapor pada guru di kantor ketika ia akan membayar di kantin anti korupsi namun tidak ada uang kembaliannya. Selain itu, ada pula seorang siswa kelas satu yang melapor kepada guru belum bisa membayar karena uangnya habis namun akan membayar di hari berikutnya. Dari hal-hal kecil tersebut, penanaman karakter kejujuran pada siswa di SD/MI Ngargorejo, Ngemplak, Boyolali sudah terlihat melalui program kantin anti korupsi.

Selama tiga minggu pelaksanaan program KKN, keuntungan penjualan kantin mengalami peningkatan yang signifikan (Gambar 4). Hal ini menunjukkan penanaman karakter kejujuran melalui program kantin anti korupsi di SD/MI Ngargorejo, Ngemplak, Boyolali siswa telah menunjukkan hasil yang sangat menggembirakan.

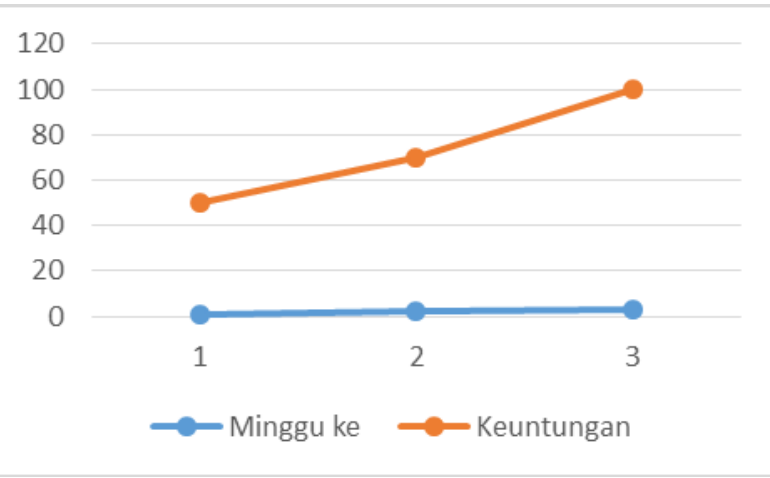

Gambar 4. Grafik Peningkatan Keuntungan Kantin Anti Korupsi

Hasil ini didukung oleh hasil penelitian Martanti (2017) yang menunjukkan ada peningkatan kejujuran santri pada siklus penelitian yang telah dilaksanakan. Kejujuran santri pada siklus I mencapai $99 \%$ dan pada siklus yang ke II mencapai $100 \%$ sehingga disimpulkan kantin kejujuran di pondok pesantren Al-Hikmah Semarang efektif dalam menanamkan nilai-nilai kejujuran siswa. 
Melalui program kantin anti korupsi di tingkat SD/MI ini, siswa secara langsung telah dilatih untuk mempunyai karakter kejujuran semenjak dini. Upaya penanaman karakter kejujuran di tingkat SMP juga telah diteliti oleh Murdiono (2016). Hasil penelitiannya menyatakan bahwa karakter kejujuran di SMP dapat ditanamkan melalui pendidikan anti korupsi terintegrasi dalam pembelajaran PKn, yaitu dengan jalan menyisipkan nilai-nilai anti korupsi pada materi pembelajaran yang relevan. Hasil yang sama ditunjukkan oleh (Anam \& Sakiyati, 2019; Atika, 2016).

Penanaman karakter melalui program KKNdik ini juga sejalan dengan pendapat Sabardila dkk (2019) yang menyatakan bahwa program penghijauan dapat menanamkan karakter peduli lingkungan pada siswa MIM Derasa-Sempu, Andong, Boyolali. Selain itu, hasil ini juga didukung oleh Setyadi, Anggrahini, Putri, dan Wardani (2019) yang menyimpulkan bahwa pendidikan karakter siswa di MTs Muhammadiyah 9 Mondokan, Sragen dapat dikuatkan melalui program penerapan budaya $5 \mathrm{~S}$ (Salam, Senyum, Sapa, Sopan, Santun).

\section{Simpulan}

Program kantin anti korupsi di di SD/MI Ngargorejo, Ngemplak, Boyolali telah terlaksana dengan baik. Keberadaan kantin anti korupsi dengan teknik pelayanan self service system dapat dijadikan sebagai media yang baik dalam penanaman karakter kejujuran siswa karena bisa melahirkan sikap dan tindakan bisa yang positif. Selain dapat menanamkan karakter kejujuran, kantin anti korupsi juga dapat membiasakan kemandirian siswa melalui hal-hal yang kecil, yaitu mengambil makanan yang disediakan sendiri, membayarkan uang yang harus dibayarkan sendiri, dan mengambil kembalian yang harus ia dapatkan sendiri.

\section{Daftar Pustaka}

Al Habib, M. (2013). Kantin Kejujuran Sebagai Sarana Pembinaan Akhlak Siswa Desa Tamiajeng, Kec. Trawas, Kab. Mojokerto. UIN Maulana Malik Ibrahim.

Alfurkan, \& Marzuki. (2020). Penguatan Nilai Kejujuran melalui Pendidikan Antikorupsi di Sekolah. Jurnal Ilmiah Pendidikan Pancasila Dan Kewarganegaraan, $\quad 4(2), \quad$ 221-231. https://doi.org/10.17977/um019v4i2p221-231

Anam, K., \& Sakiyati, I. D. (2019). Kantin Kejujuran Sebagai Upaya Dalam Pembentukan Karakter. Al Qalam: Jurnal Ilmiah Keagamaan Dan Kemasyarakatan, $\quad 13(1), \quad 21$. https://doi.org/10.35931/aq.v0i0.130

Atika, N. (2016). Pengaruh Pelaksanaan Kantin Kejujuran Dalam Membentuk Akhlak Siswa Di SDN 114 Palembang. El-Idare: Jurnal Manajemen Pendidikan Islam, 2(2).

Budhiman, A. (2017). Gerakan Penguatan Pendidikan Karakter.

Fitriansyah, R., Fatinah, L., \& Syahril, M. (2020). Critical Review: Professional Development Programs to Face Open Educational Resources in Indonesia. Indonesian Journal on Learning and Advanced Education (IJOLAE), 2(2), 109-119. https://doi.org/10.23917/ijolae.v2i2.9662

Martanti, F. (2017). Penanaman Nilai-Nilai Kejujuran Melalui Media Kantin Kejujuran di Pondok Pesantren Al Hikmah Semarang. SOSIO DIALEKTIKA- Jurnal Ilmu Sosial-Humaniora, 2(1), $43-56$.

Murdiono, M. (2016). Pendidikan Anti Korupsi Terintegrasi dalam Pembelajaran PKn untuk Menanamkan Karakter Kejujuran di SMP. SOCIA: Jurnal Ilmu-Ilmu Sosial, 13(1), 1-12. https://doi.org/10.21831/socia.v13i1.9910

Sabardila, A., Budiargo, A. D., Wiratmoko, G., Himawa, J. A., Triutami, A., Intansari, A., ... Suistri. (2019). Pembentukan Karakter Peduli Lingkungan melalui Kegiatan Penghijauan pada Siswa. 1(2), 35-41. https://doi.org/10.23917/bkkndik.vli2.10763

Samani, M., \& Hariyanto. (2013). Konsep dan Model Pendidikan Karakter (Ketiga; A. Kamsyach, Ed.). Bandung: PT Remaja Rosdakarya.

Setyadi, Y. B., Anggrahini, T. O., Putri, N., \& Wardani, K. (2019). Penerapan Budaya $5 S$ sebagai Penguatan Pendidikan Karakter Siswa di MTs Muhammadiyah 9 Mondokan, Sragen. 1(2), 7076. https://doi.org/10.23917/bkkndik.vli2.10774

Undang-Undang Republik Indonesia no 20 Tahun 2003 tentang Sistem Pendidikan Nasional. (2003).

Undang-Undang Republik Indonesia Nomor 30 Tahun 2002 tentang Komisi Pemberantasan Tindak Pidana Korupsi. (2002). https://doi.org/10.1007/978-1-4614-7990-1 